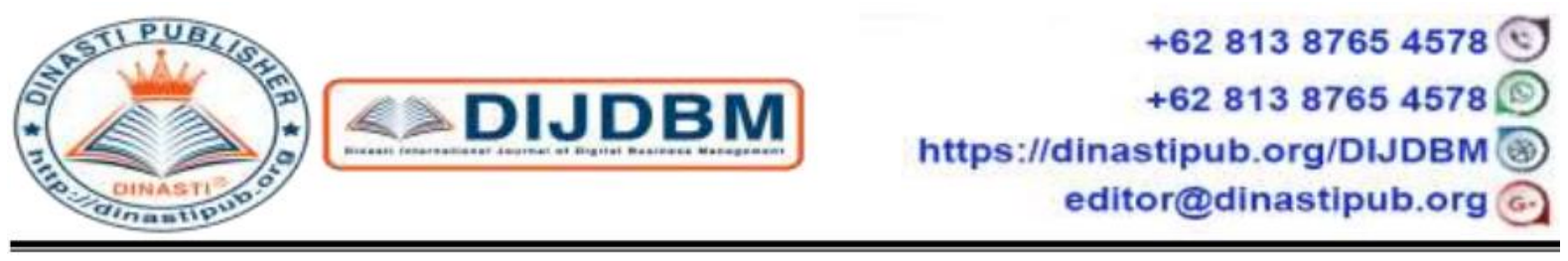

\title{
DETERMINANT OF GOVERNMENT BOND YIELDS
}

\section{Priyo Adiwibowo ${ }^{1)}$, Pardomuan Sihombing ${ }^{2)}$}

${ }^{1,2)}$ Magister Manajemen, Universitas Mercubuana, Jakarta, Indonesia

\begin{tabular}{|c|c|}
\hline $\begin{array}{l}\text { ARTICLE INFORMATION } \\
\text { Received: } 2 \text { January } 2020 \\
\text { Revised: } 9 \text { January } 2020 \\
\text { Issued: } 13 \text { January } 2020 \\
\text { Corresponding author: } \\
\text { Priyo Adiwibowo } \\
\text { E-mail: }\end{array}$ & $\begin{array}{l}\text { Abstract: This study aims to analyze the influence of } \\
\text { determinant factors: (i) exchange rates, (ii) inflation, (iii) } \\
\text { CDS spreads, (iv) bid-ask spreads, (v) overnight rate, } \\
\text { (vi) CB's rate (Central Bank Rate), and (vii) oil prices } \\
\text { on Government bond yields. The data used are monthly } \\
\text { data in the period } 2012 \text { - 2018. The research method used } \\
\text { is the Vector Auto Regression (VAR) approach. Our } \\
\text { analysis indicated that the determinant factors have } \\
\text { impact on government bond yields. Based on the } \\
\text { analysis of the impulse response function (IRF), the } \\
\text { yield is to respond to any shocks given by the long term. } \\
\text { While through forecast error variance decomposition } \\
\text { (FEVD) analysis, found that CDS spreads and oil prices } \\
\text { contributed significantly to the movement of } \\
\text { Government bond yields. } \\
\text { Keywords: Government bond yield, determinant } \\
\text { factors, Vector Auto Regression, impulse response } \\
\text { function, forecast error variance decomposition. }\end{array}$ \\
\hline
\end{tabular}

\section{INTRODUCTION}

In the context of a country, one type of financing that is often used is bonds. Government financing through the country makes the Indonesian bond market continues to grow, indicated by the trend of the value of bond emissions in the market. The average issuance growth during 2008-2018 reached 19\% with outstanding bonds in 2018 reaching Rp2,421.84 trillion.

On the other hand, bond yield will have great impact on the allocation of spending, especially on the amount of interest expenditure. In the State Budget 2019, the allocation of interest expenditure around IDR275.9 trillion, or 10.4 percent of the State Budget 2018 outlook.

The above phenomenon certainly becomes something interesting to study. Historically, there have been a number of researches related to this problem. Ross (2015) saying that bond yields are influenced by several variables: (1) inflation expectations, (2) interest rate risk. (3) liquidity, (4) potential defaults, and (5) tax rates. 
Meanwhile, according to Afonso and Rault (2010), one important factor affecting bond yields is inflation. Low inflation also represents a low risk in the economic sphere and vice versa. This result was also supported by Yu Hsing (2015) who stated that inflation expectations had a positive relationship with bond yields. Nevertheless, there are different results submitted by Perovic (2015), he stated that inflation is negatively correlated and significant to bond yields. Another case with Muharam (2011) which states that there is no correlation between inflation and bond yields.

Other factors are oil prices, interest rates and exchange rates. Muharam (2011) argues that oil prices are positively and significantly correlated to bond yields. On the other hand, Idham (2014) argues that if there is a change in oil prices, bond yields will react negatively and significantly.

While changes in exchange rates have a positive correlation with bond yields. It is in line with Gadanecz (2014) that the exchange rate is positively correlated to bond yields. Although there is an influence between macroeconomic factors and bond, it is necessary to pay attention to the inconsistency of previous research.

By looking at the phenomenon above, which is preceded by high yields on Government bonds which tend to put pressure on the State Budget and the inconsistency problem of some of the previous studies above, the phenomenon becomes a strong foundation to develop research by adding other factors that have an effect on Government bond yields .

\section{LITERATURE REVIEW}

\section{Term Interest Structure Theory}

This theory is an opinion which states that the amount of the interest rate will be influenced by the time of maturity. According to Martellini (2003), TSIR is a translation of interest rates according to a certain time to maturity. The length of time to maturity will determine the amount of the interest rate. This collection of various tenors will produce a yield curve. TSIR or better known as the yield curve is more easily defined as the correlation between yield and maturity.

\section{Asset Demand Theory}

According to Mishkin (2009), several factors that affect bond demand will ultimately affect bond prices and yields as follows: (i) Wealth, the amount of asset demand has a positive relationship with wealth, (ii) Expectations on yields, the amount of asset demand has a positive relationship with the expected return on alternative assets. (iii) Risk, the amount of asset demand has a negative relationship with the risk of returns on alternative assets and (iv) Liquidity, the number of asset requests has a positive relationship with liquidity on alternative assets.

Gadanecz et al (2014) suggested several reasons why exchange rate risk is one of the factors that greatly influences bond yields. Jaramillo and Weber (2012) conclude that there is a positive and significant effect between inflation and EM bond yields. Regarding the bid-ask spread, Soebagiyo and Panjawa (2016) can be concluded that in the short term there is a negative and significant relationship between the level of liquidity and yield. Soebagiyo and Panjawa (2016) also concluded that there was a positive influence between the movement of 
the CB's rate and yield. Fitriana and Rohayati (2013) concluded that there was a positive relationship between the movements of overnight rate and yields. Zheng (2015), CDS spread has a positive effect on government bond yields. Simatupang (2016) suggests that world crude oil prices can be used as one of the independent variables in predicting the movement of government bond yields.

\section{HYPOTHESIS}

Effect of exchange rates on Government bond yields. Gadanecz et al (2014) suggest several reasons why exchange rate risk is one of the factors that is very influential on the level of domestic bond yields of a country. The depreciation of the local currency which is beyond expectations will encourage foreign investors to release their ownership of assets in the local currency which will ultimately reduce liquidity and increase the level of yield requested by investors.

\section{H1: Exchange rate has a positive effect on Government bond yields.}

Influence of inflation on Government bond yields. Mankiw (2004) describes inflation as an increase in the general level of prices in an economy. The increase in prices can be measured by the Consumer Price Index (CPI), which is a measurement of the general level of costs of goods and services purchased by the general public. Jaramillo and Weber (2012) conclude that there is a positive and significant effect between inflation and EMs government bond yields

\section{H2: Inflation has a positive effect on Government bond yields}

Effect of Bid-Ask spread on Government bond yields. Market liquidity can generally be explained as the level of how easily investors or portfolio owners can carry out large-scale financial transactions at relatively low price levels and with limited impact on asset price levels (Bank for International Settlements, 2016). Zheng (2015) cites a study conducted by Beber et al (2009) and Favero et al (2010) suggesting that the difference between the asking price and the price offered on government bonds (spread) is the best indicator of measuring the liquidity risk of state bonds compared to other indicators such as trading volume and the number of outstanding bonds Soebagiyo and Panjawa (2016) revealed that in the short term there is a negative and significant relationship between the level of liquidity and yield.

\section{H3: Bid-Ask spread has negative effect on Government bond yields}

Effect of CB's rate on Government bond yields. Bank Indonesia (BI) will raise the CB's rate if expected inflation is to exceed the set target, otherwise BI will lower the CB's rate if expected inflation is below the target set. Several studies conducted by Soebagiyo and Panjawa (2016) concluded that there is a positive influence between the CB's rate and yield.

\section{H4: CB's rate has a positive effect on Government bond yields}

Effect of overnight rates on Government bond yields. Fitriana and Rohayati (2013) concluded that there was a positive relationship between the overnight rate movement and yields.

\section{H5: $\mathrm{O} / \mathrm{N}$ rates have a positive effect on Government bond yields}

Effect of CDS spread on Government bond yields. Zheng (2015) argued that the debt to GDP ratio, current account deficit and fiscal deficit had a positive relationship with the level 
of government bond yields. According to a study compiled by the Fiscal Policy Agency (2013), there has been a tendency for increasing CDS spreads in developing countries in recent years. In this study, the CDS data on Indonesia's five-year bond spread will be used as one of the independent variables that is considered to represent the level of default risk in measuring the factors that influence the level of Indonesian bond yields.

\section{H6: CDS spread has a positive effect on Government bond yields.}

Effect of oil prices on Government bond yields. Simatupang (2016) argues that world crude oil prices can be used as one of the independent variables in predicting bond yields. Hypothetically, rising energy commodity prices could hoist inflation rate which is generally followed by an increase in the CB's rate. In the medium term, the increase in the CB's rate will cause an increasing in expected yield.

\section{H7: Oil prices have a positive effect on Government bond yields}

\section{CONCEPTUAL FRAMEWORK}

The relationship between Government bond yields and its determinants can be broadly described in the framework of this study as follows:

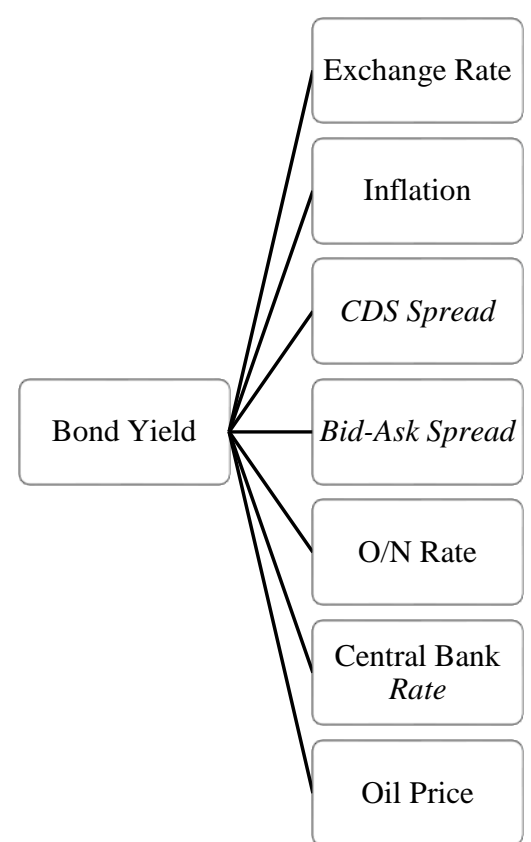

Figure 1. Conceptual Framework

\section{RESEARCH METHODS}

This type of research used in this study is a quantitative approach with a Vector Auto Regression (VAR) Model (if the data used is stationary and no cointegration), or the Vector Error Correction Model (VECM) approach (if the data used is then known to be non-stationary but there is cointegration).

Measurement of variables in this study uses a time series analysis tool using the VAR model which is processed using the Eviews 10. This research was conducted using secondary 
data, monthly data in the period 2012 to 2018. The population in this study is Government Bonds. Meanwhile, the sample of this research is the 10-year Government Bond-Rupiah Denomination. Data sourced from financial sites such as Bank Indonesia and Bloomberg websites.

\section{Descriptive statistics}

Exchange rate. In 2018, Pressure on the Rupiah was affected by the decline in Indonesia's net export performance. High foreign exchange demand was influenced by rising imports until the third quarter of 2018 in line with solid domestic demand. These global and domestic conditions causes increasing net foreign exchange demand and put pressure on the Rupiah from February 2018 to October 2018. The Rupiah in this period depreciated $12.5 \%$, where the Rupiah had reached the level of Rp15,235 per US dollar. Rupiah volatility also increased on average to $8.1 \%$, from $7.0 \%$ in January 2018.

With these dynamics, the Rupiah in 2018 weakened by an average of $6.05 \%$ (yoy) to a level of Rp14,246 per US dollar from Rp13,385 per US dollar in 2017. Point-to-point (ptp), Rupiah weakened 5.65\% and closed at Rp14,380 per US dollar at the end of 2018. However, the weakening of the Rupiah was still lower than the depreciation of other countries such as Indian rupees, South African rand, Brazilian real, and Turkish lira.

In the last 3 years, it can be seen that the average exchange rate is at the level of Rp. 13,578.69 with the highest depreciation at the level of Rp. 15,177.00 which occurred in the initial phase of the US-China trade crisis at the end of 2018.

Inflation. Inflation in 2018 remains manageable low within the target range of $3.5 \pm$ $1 \%$, although at the same time the Rupiah is depreciating. CPI inflation at the end of 2018 was recorded at 3.13\%, making inflation within the target range for 4 consecutive years. 2018 inflation was recorded low, both when compared with the achievement of inflation in 2017 (3.61\%) and with the historical average of the last four years (4.59\%). One side of low inflation is influenced by cyclical factors from global and domestic.

From the global side, low inflation is influenced by declining global food prices, which in turn has a positive effect on domestic food price control. From the domestic side, controlled demand also affects inflationary pressures that continue to decline.

Statistically, in the last 3 years, the average inflation was at the level of 4.23 percent with the highest inflation rate at the level of 8.36 percent at the end of 2014.

Bid-Ask Spread. Global uncertainty influences the determination of investors' decisions in placing their funds in each instrument. Government bond, one of the risk-free instruments, is an attractive investment alternative. In the last 3 years, the average bid-ask spread is at the level of 8.08 percent with the highest level at 15.20 which occurred in September 2013. This condition has been an issue since early 2013 where foreign investors are worried weakening of the Rupiah exchange rate which can erode potential profit. Investors are also considering factors such as a review of the government's plan to increase fuel oil (BBM) and the current account deficit 
CB's rate. To increase the level of liquidity, banks compete to get the maximum amount of funds from the public by increasing deposit rates, namely deposit rates. In the last 3 years, the average was at the level of 6.45 percent with the highest level at the level of 7.75 percent at the end of 2014. This condition reflects that at that time the liquidity in the community was excessive while bank liquidity was reduced.

Overnight Rate. Based on data, during 2013-2016, the overnight rate reached a range of 5.5 to 6.0 percent. The position is relatively the same as semester 2 of 2018 . When examined more closely, for the period of 2015 for example, a number of economists noted that this period occurred due to an increase in the Rupiah interest rate in the swap market in line with the increased demand for foreign currency hedges in the market. Meanwhile for semester 2 of 2018, liquidity tightening occurred due to the increase in the BI benchmark interest rate. For this reason, banks are more active in transactions on the overnight rate money market in order to secure short-term liquidity.

CDS Spread. Indonesia's CDS for the 5Y tenor moved quite volatile in the September 2012-May 2013 period. The 5Y CDS surged through the 213bps level in June due to the impact of rising fuel prices and global uncertainty. After that, CDS continued to move up and reached the 246bps level in August, as inflation remained high in the three months. After a decline due to inflation began to be controlled, CDS rose again as of November 2013 at 224bps. This is due to the decline in Indonesia's economic growth to 5.6\% in Q3-2013 and the high CAD of $3.8 \%$ of GDP. Widening spreads also indicate there is selling pressure on government bond and yields tend to rise. Meanwhile, the future movement of Indonesia's CDS will be influenced by developments in US and China trade issues and shifting of foreign investor funds that still have the potential to enter the country

Oil Prices. The world crude oil price in Q1 2018 still increased to USD64.6 per barrel. OPEC and non-OPEC production restrictions in late November 2017, a decline in oil production by OPEC countries in December 2017, a decrease in the number of rigs in the United States, increased demand in India and South Korea, and geopolitical reasons in the Middle East driving factor of rising world crude oil prices.

In the last 3 years, the average oil price was at 51.96 with the highest price at 106.54 in August 2013. Global uncertainties have affected fluctuations in commodity prices throughout the year.

\section{Research result \\ Stationary Test}

The stationary test results show that by re-testing the stationarity, all variable were stationary in the first differences condition. In other words, the null hypothesis which states that there is a unit root (or data is not stationary) is rejected. 


\section{FINDINGS AND DISCUSSION}

Table 1. Unit Root Test

\begin{tabular}{ccccc}
\hline \multirow{2}{*}{ Variable } & \multicolumn{2}{c}{ Level } & \multicolumn{2}{c}{ First Difference } \\
\cline { 2 - 5 } & P-Value & Status & P-Value & Status \\
\hline SUN & 0.1895 & not stationary & 0.0000 & stationary \\
KURS & 0.3957 & not stationary & 0.0000 & stationary \\
INFLASI & 0.2950 & not stationary & 0.0000 & stationary \\
BAS & 0.0003 & stationary & 0.0001 & stationary \\
SBI & 0.3762 & not stationary & 0.0000 & stationary \\
ON & 0.3320 & not stationary & 0.0000 & stationary \\
CDS & 0.3363 & not stationary & 0.0000 & stationary \\
OIL & 0.4595 & not stationary & 0.0000 & stationary \\
\hline
\end{tabular}

Notes: Unit root test using Augmented Dickey Fuller (ADF)

\section{Optimum Lag Selection}

After conducting the data stationarity test, the next step is to choose the optimum lag. Based on the test results, a VAR system is said to be stable if all the roots or roots have modulus smaller than one. In this study, based on the VAR stability test has been stable if the modulus range $<1$. This is evidenced by the absence of the inverse root value of the AR characteristic polynomial coming out of unit circle (see Figure 2).

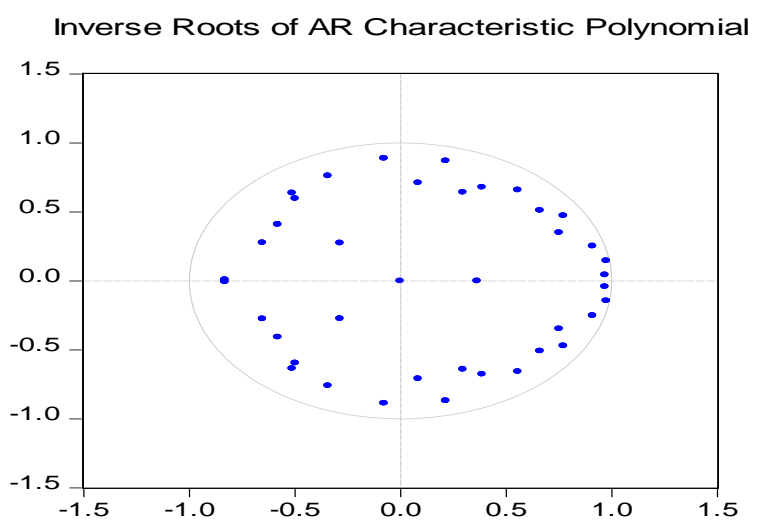

Figure 2. Inverse Roots of AR Characteristic Polynomial

This stability test can be fulfilled until the 5th lag, thus the maximum lag of the VAR model is 5 . Testing the optimal lag length is very useful to eliminate the autocorrelation problem in the VAR system. The determination of the optimal lag in this study is based on the Schwarz information criterion (SIC) criteria, which is lag 1.

\section{Cointegrity Test}

This study uses a cointegration test method from the Johansen Trace Statistics test. This test is to find out whether or not there is a long-term influence for the variables we will examine. If it is proven that there is cointegration, then the VECM stage can be continued. But if it is not proven, then VECM cannot be continued. The results showed that there is a cointegration relationship which is shown by the existence of 1 cointegration equation based on trace-statistic 
values at the real level of 0.05 . Thus the VAR model above can be developed into a VECM model.

\section{VECM Estimation Results}

VECM estimation results will obtain a short-term and long-term relationship between the exchange rate, inflation, bid-ask spread, CB's rate, overnight rate, CDS spread, oil prices and yields. In this results, yield as the dependent variable, while the independent variables are inflation, bid-ask spread, CB's rate, overnght rate, CDS spread, and oil prices. The long-term effects and its influence can be seen in table 2 .

\section{Table 2. VECM Results}

\begin{tabular}{|c|c|c|}
\hline Variable & Koefisien & T-stats \\
\hline \multicolumn{3}{|c|}{ Long Term } \\
\hline $\begin{array}{c}\text { KURS(- } \\
1)\end{array}$ & -1.537534 & $\begin{array}{c}{[-} \\
13.2663]\end{array}$ \\
\hline $\operatorname{INF}(-1)$ & -0.101017 & $\begin{array}{c}{[-} \\
3.52203]\end{array}$ \\
\hline $\mathrm{BAS}(-1)$ & 0.181027 & $\begin{array}{c}{[} \\
3.84576]\end{array}$ \\
\hline SBI(-1) & -0.531145 & $\begin{array}{c}{[-} \\
1.86685]\end{array}$ \\
\hline $\mathrm{ON}(-1)$ & 0.556726 & $\begin{array}{c}{[} \\
2.56578]\end{array}$ \\
\hline CDS(-1) & -0.491216 & $\begin{array}{c}{[-} \\
8.44057]\end{array}$ \\
\hline OIL(-1) & -0.331413 & $\begin{array}{c}{[-} \\
7.84415]\end{array}$ \\
\hline
\end{tabular}

\section{Impulse Response Function (IRF)}

IRF analysis is used to show the yield response to shock given by the independent variable.

1) Exchange Rate Shocks

A shock of one standard deviation on the exchange rate, the yield will react positively in the long term starting in the fourth period. Although in the second and third periods the response level is slightly decreased or negative.

2) Inflation Shocks

A shock of one standard deviation in inflation, the yield will react positively by 0.0016 in the second period. A significant increase occurred in the seventh period in which yields would respond by 0.0129 .

3) Bid-ask spread Shocks

A shock of one standard deviation in the bid-ask spread, the yield will react negatively in the long run. 
4) CB's rate Shocks

Despite the shock of the CB's rate on yield in the long run responded positively even though in the third period it responded negatively by minus 0.0013 .

5) Overnight Rate Shocks

A shock of one standard deviation on the overnight rate, the yield will react positively starting in the third period of 0.0161 . In the long run the response of yield to this shock will continue to be positive.

6) CDS spread Shocks

A shock of one standard deviation on the CDS spread, the yield will react positively in the long run.

7) Oil prices Shocks

A shock of one standard deviation in the price of oil, in the long run yield will react positively by 0.0180 starting in the second period.

\section{Forecast Error Variance Decomposition (FEVD)}

Statistically, in the short term, the yield will be greatly influenced by the yield itself, as shown in the figure 3 from the estimated FEVD results.

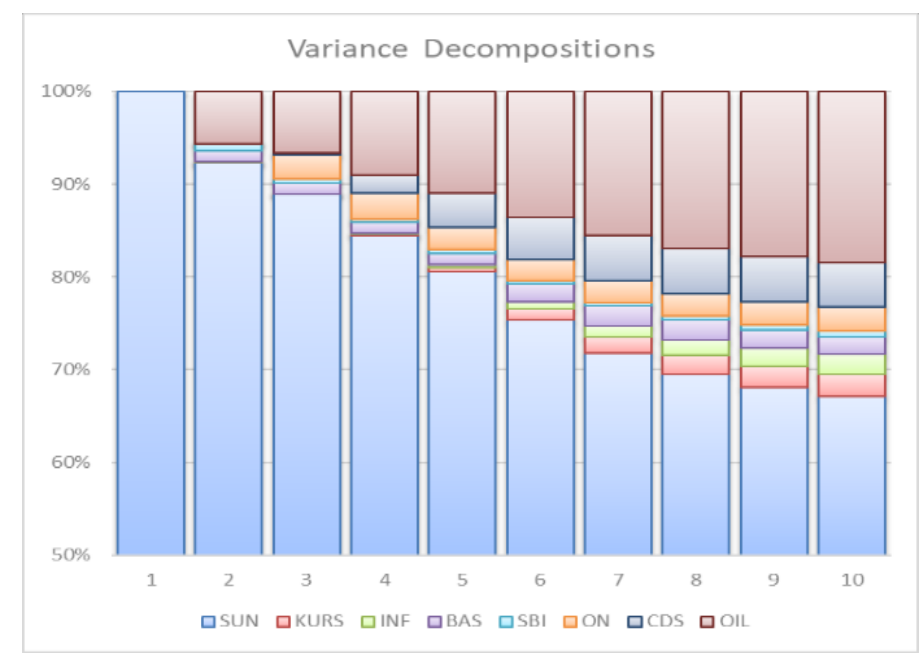

Figure 3. FEVD Results

The dominant contribution to the change in yield over the long term or tenth period from the estimated FEVD results is as follows: exchange rate $(2.35 \%)$, inflation $(2.13 \%)$, CDS spread $(4.81 \%)$, bid-ask spread $(1.92 \%)$, overnight rate $(2.64 \%)$, CB's rate $(0.60 \%)$ and oil price $(18.41 \%)$.

\section{Discussion}

\section{Effect of exchange rates on Government bond yields}

Statistically, the exchange rate has a positive effect on changes in yield. Through IRF analysis, a shock of one standard deviation on the exchange rate, the yield will react positively in the long term starting in the fourth period. Meanwhile, exchange rate has a contribution of 
2.35\%. Depreciation of the Rupiah, will encourage foreign investors to release their ownership of Rupiah-denominated assets which in turn will reduce liquidity and increase the yields requested by investors. This result is in line with Gadanecz et al. (2014), which showed exchange rate has a positive effect on government bond yield.

\section{Effect of inflation on Government bond yields}

Statistically, inflation has a positive effect on changes in yield. Through IRF analysis, a shock equal to one standard deviation in inflation, the yield will react positively in the second period and increase significantly in the seventh period. In other words, yield responsiveness to changes in inflation where shocks or shock that occur in inflation will affect yield changes that are statistically increased or positive. Meanwhile, inflation has a contribution of $2.13 \%$.

Inflation as a process of increasing prices in general and continuously, of course, has implications for investors' expectations of the return of their assets. Increasing inflation will certainly be a risk in itself which will reduce the returns that investors will receive in the future. Thus, the positive effect of changes in inflation on yields is quite relevant to current conditions.

It is in line with Jaramillo and Weber's (2012) research which concluded that there is a positive and significant effect between inflation and EMs bond yields. Sihombing (2015) and Kurniasih (2016), which concluded that there was a positive and significant influence between inflation and government bond yields.

\section{Effect of CDS spread on Government bond yields}

Statistically, CDS spread has a positive effect on changes in yield. Through IRF analysis, a shock of one standard deviation on the CDS spread, the yield will react positively which means widening the CDS spread will cause an increase in yield. Meanwhile, the contribution to yield changes through analysis of variance decomposition by involving the determinant factors above, CDS spread has a contribution of $4.81 \%$.

CDS spread as an indicator in measuring a country's default risk becomes a determinant factor that affects the yield requested by investors. The widening of the CDS spread has a longterm impact on yield. This condition shows that investors consider the increase in the CDS spread as an indication of the risk of government default that must be converted into return expectations so that the yield requested will also increase.

The results is in line with Zheng (2015). These things in parallel can increase a country's default risk and encourage an increase in Government bond yields.

\section{Effect of Bid-Ask spread on Government bond yields}

Statistically, bid-ask spread has a negative effect on changes in yield. Through IRF analysis, a shock of one standard deviation on the bid-ask spread, the yield will have a negative effect, which means that widening the bid-ask spread will cause a decrease in yield in the long run. Bid-ask spread has a contribution of $1.92 \%$.

When the government has been able to manage bond issuance more efficiently by considering funding needs that are smoother, the government's bargaining power will be stronger so that in auction transactions, when conditions are in high demand, the government 
has a strong position to offer low yields. Thus, widening the bid-ask spread over the long term has a negative effect which will reduce the yield level.

Based on Zheng's study (2015) citing a study conducted by Beber et al (2009) and Favero et al (2010) suggested that the difference between the requested price and the price offered on state bonds (spread) is the best indicator in measuring the liquidity risk of state bonds.

\section{Effect of overnight rate on Government bond yields}

Statistically, the overnight rate rate has a positive influence on changes in yield. Through IRF analysis, a shock of one standard deviation on the overnight rate, the yield has a positive effect on the long term yield. While the contribution to yield changes through analysis of variance decomposition by involving the determinant factors above, the overnight rate contributed $2.64 \%$.

The vulnerability that occurs in liquidity will directly be reflected in lending and Overnight rates. Under tightening conditions, the risk of return on assets is higher. Thus, in these conditions, investors will ask for a high return on asset returns such as government and corporate debt securities. Amid the increase in risk, the yield requested by investors will also increase.

It is in line with research conducted by Fitriana and Rohayati (2013) concluding that there is a positive relationship between the movements of the overnight rate and yield. In this study, the effect of changes in the overnight rate in the long run will be responded positively by yield.

\section{Effect of CB's rate on Government bond yields}

Statistically, the CB's rate has a positive effect on changes in yield. Through IRF analysis, CB's rate shock of one standard deviation to yield in the long run is responded positively. A positive relationship between the CB's rate and inflation as a consequence of decreased expectations of the returns to be obtained by investors. Thus, of course investors will expect high returns, which are reflected in rising yields. Several studies conducted, among others, by Soebagiyo (2016) concluded that there is a positive influence between the CB's rate and yield. Meanwhile, if seen from the contribution to the change in yield over the long term through the analysis of variance decomposition by involving the determinant factors above, the CB's rate has a contribution of $0.60 \%$.

Central Bank in general will raise the CB's rate if inflation in the future is expected to exceed the target set, otherwise $\mathrm{CB}$ will reduce the CB's rate if inflation in the future is estimated to be below the target set. This means that risk on assets can be reflected in the movement of the CB's rate. With an increase in risk for assets, including government bonds, the yield requested by investors will also increase to accommodate the expected return expectations.

Soebagiyo and Panjawa (2016) concluded that there is a positive influence between the CB's rate and yield movements. This means that the results of this study are consistent with the results of previous studies. 


\section{Effect of oil prices on Government bond yields}

Statistically, changes in oil prices to yield in the long run have a positive effect. Through IRF analysis, a shock of one standard deviation on the oil prices, in the long run the yield will react positively. Meanwhile, if seen from the contribution to the change in yield over the long term through the analysis of variance decomposition by involving the determinant factors above, oil prices have the largest contribution of $18.41 \%$.

The effect of oil prices is considered to have a fairly long time lag on yield changes, bearing in mind that rising oil prices do not directly affect yields. However, the chain effect will increase the rate of inflation which is generally followed by an increase in the benchmark interest rate. In the medium and long term, the increase in the benchmark interest rate will be followed by increased risk of assets including Government debt. Thus, the transmission is very relevant to the results of the study.

The results of this study are in line with the study of Simatupang (2016) which suggests that world crude oil prices can be used as one of the independent variables in predicting the yield of government bonds.

\section{CONCLUSION AND SUGGESTION Conclusion}

Our analysis indicated that exchange rates, exchange rates, bid-ask spreads, CB rates, overnight rates, CDS differences, and oil prices have influence on Government bond's yield. The shock factors on yield analyzed through impulse response function (IRF) and variance decomposition (FEVD) provide us the following information:

1) Exchange rates. Following our analysis previously by observing yield response on shock of exchange rate, this shock has statistically significant positive impact on yield. This result is inline with our hypothesis in which our FEVD analysis show the contribution of 2,35\% from exchange rate.

2) Inflation. Statistically, inflation has positive impact on yield in the long term eventhough it also occurs in the short term as well. This shows that investors consider inflation as an investment risk inline with our hypothesis which mentioned that inflation wii have a highly significant impact on Government bond's yield. Our analysis through FEVD shows that inflation countribute to $2,13 \%$ on Government bond's yield changes.

3) CDS Spread. Based on statistical results, an increase in CDS spread has long-term impact on Government bond's yield. Our analysis through FEVD shows that CDS spread contribute to $4,81 \%$ on Government bond's yield changes. This condition becomes relevant considering the sustainability of debt service has to be maintained to prevent default risk.

4) Bid-ask spread. Statistically, there is a negative impact of bid-ask spread on yield in the long-term. Government need to pay attention on this variable as our analysis through FEVD shows that it contributes to $1,92 \%$ on Government bond's yield changes.

5) Overnight rate. Our study shows that changes in overnight rate rates will have a positive but indirect impact on Government bond's yield in the long-term inline with our hypothesis. in the long run will be responded positively by the results. Although this variable has an 
indirect impact, our analysis through FEVD shows that it contributes to 2,64\% on Government bond's yield changes.

6) CB's rate. Our study shows that changes on CB's rate in the long run will have positive impact on Government bond's yield as this variable has a positive correlation with inflation. In which, an increase in CB's rate will be translated into higher inflation expectation thus increasing expected yield required by investors.

7) Oil prices. Our study shows changes on oil price in the medium-term will have a positive impact on Government bond's yield. Our analysis through FEVD shows that this variable has dominant impact on Government bond's yield compared to other variables. Investors will therefore consider the increase of oil price as an increase in Government bond's risk which will in turn translated into higher Government bond's yield.

\section{Suggestion}

Referring to our conclusions, we can provide the following recommendation for Government as issuer and future researchers for improvement:

1) For the Government, by looking at the impact and portion of the contribution, it is necessary for the Government to look at variables mentioned here as part of mitigation effort and part of the strategy for issuing Government bond. The government is expected to develop a scenario or stress-test framework to anticipate a surge in interest expenditures.

2) For the future researcher, this research is limited to only examining the determinant of yield with 10 years tenor as a benchmark for Rupiah-denominated Government bonds, thus in subsequent studies it is expected to be able to use other instruments with different denominations for instance USD as the dependent variable to produce different variants and broadening the scope of analysis. Future studies are expected to look at other variables beyond the variables mentioned in this study in order to see the implications for other sectors. The selection of research time intervals should capture and consider in detailed on significant changes both individually data and economic events that occur. This is suggested as a way to see the sensitivity of changes in yields that are deeper and more specific.

\section{REFERENCE}

Afonso, Antonio and Rault, Christophe, Long-Run Determinants of Sovereign Yields (2010). CESifo Working Paper Series No. 3155. Available at SSRN: https://ssrn.com/abstract $=1660368$

Bank Indonesia. (2013). Kodifikasi Peraturan Bank Indonesia: Likuiditas Rupiah, Pasar Uang Antar Bank. Pusat Riset dan Edukasi Bank Sentral (PRES). Tersedia di: https://www.bi.go.id/id/peraturan/kodifikasi/bank/Pages/1.1.1.5.\%20Pasar\%20Uang\% 20Antar\%20Bank.aspx

Bank Indonesia. (2016). Gubernur BI: Bank Indonesia Menetapkan 7-day Repo Rate Sebagai Suku Bunga Kebijakan Baru. Jakarta: Bank Indonesia. Tersedia di: http://www.bi.go.id/id/ruang-media/siaranpers/Pages/sp_182916.aspx. 
Bank of International Settlement. (2016). Fixed income market liquidity. CGFS Papers No.55. Tersedia di: https://www.bis.org/publ/cgfs55.pdf.

Beber, Alessandro and Brandt, Michael W. and Kavajecz, Kenneth A. (2009). Flight-to-Quality or Flight-toLiquidity? Evidence from the Euro-Area Bond Market. The Review of Financial Studies, Vol. 22, Issue 3, pp. 925-957.

Favero, C., Pagano, M., and von Thadden, E.-L. (2010). "How does liquidity affect government bond yields?". Journal of Financial and Quantitative Analysis, 45 (1), 107-134.

Fitriana, E.S., \& Rohayati, S. (2013). Pengaruh Suku Bunga Terhadap Harga Obligasi Melalui Yield Obligasi. Jurnal Ilmu Manajemen, 1(3).

Gadanecz, B., Miyajima, K., and Shu, C. (2014). "Exchange rate risk and local currency sovereign bond yields in emerging markets". BIS Working Paper No 474.

Hsing, Yu. 2015. Determinants of the Government Bond Yield in Spain: A Loanable Funds Model. International Journal of Financial Studies.

Idham, Ahmad. 2014. Analisis Faktor Determinan yang Mempengaruhi Yield Obligasi (Studi Empiris Pemerintah Indonesia 2009:1-2013:12). Yogyakarta : Skripsi Universitas Gajah Mada

Jaramillo, Laura and Anke Weber (2012). "Bond Yields in Emerging Economies: It Matters What State You Are In". IMF Working Paper, Vol.12, No.198, hal 1-24.

Kurniasih, Augustina dan Yulia Restika (2015). "The Influence of Macroeconomic Indicators and Foreign Ownership on Government Bond Yields: A Case of Indonesia”. Mediterranean Journal of Social Sciences, Vol.6, No.5, hal 34-42.

Mankiw, N. Gregory. 2007. Makroekonomi, Edisi Keenam. Jakarta: Penerbit Erlangga.

Muharam, Harjum. 2011. Model Determinan Imbal Hasil Obligasi Pemerintah. Semarang: Disertasi Universitas Diponegoro.

Perovic, Lena Malesevic. 2015. The Impact of Fiscal Positions on Government Bond Yields in CEE Countries. Journal of Economic System.

Ross, S., Westerfield, R., and Jordan, B. 2015. Fundamental of Corporate Finance. Mc Graw Hill Education. Jakarta: SalembaEmpat.

Sihombing, Pardomuan. 2014. Determinan Yield Curve Surat Utang Negara (). Tesis. Bogor: Institut Pertanian Bogor

Sihombing, Pardomuan. 2018. Corporate Financial Management. Bogor: IPB Press

Simatupang, B. (2016). Kajian Determinan Tingkat Imbal (Yield) Hasil Surat Berharga Negara [PowerPoint Slides]. Diambil dari materi presentasi pada kegiatan diskusi kelompok terpumpun antara DJPPR Kemenkeu dan Universitas Katolik Parahyangan Bandung, 28 April 2016.

Soebagiyo, D., \& Panjawa, J.L. (2016). Determinan Surat Utang Negara () dengan Pendekatan ECM. The 3rd University Research Colloquium. Kudus: LPPM Muhammadiyah.

Zheng, Q. (2015). The Explanatory Power of Credit Ratings on Government Bond Yields Spreads: A Comparison Study of Developed Countries and Developing Countries (Master Thesis). Erasmus University Rotterdam, Rotterdam, Belanda 